Ausloos, "The Story of Ehud and Eglon," OTE 30/2 (2017): 225-239

\title{
The Story of Ehud and Eglon in Judges 3:12-30: A Literary Pearl as a Theological Stumbling Block
}

\author{
HANS Ausloos (F.R.S.-FNRS - UNIVERSITE CATHOLIQUE DE LOU- \\ VAIN / UNIVERSITY OF THE FREE STATE)
}

\begin{abstract}
Making use of numerous stylistic devices and playing with words, the author of Judg 3:12-30 has succeeded in creating a masterpiece of literature that challenges its reader. Moreover and simultaneously, this story, that narrates the brutal murder of king Eglon by the Israelite Ehud, is very problematic from a theological perspective. The present article offers firstly an analysis of Judg 3:12-20 and subsequently demonstrates how a specific and often-overlooked aspect of the violent nature of the text-after all, king Eglon has been utilized by YHWH to restore obedience among the Israelites - holds a key to unlocking the theological intention of this text.
\end{abstract}

KEYWORDS: Ehud; Eglon; Judges; Violence; Judges 3.

\section{A INTRODUCTION}

Prof. Izak (Sakkie) Spangenberg undoubtedly is one of those scholars who substantially have influenced OT scholarship, not at least within the South African context. Notwithstanding the fact of even being considered as "heretic" by some, he spent decades of his life in analysing numerous biblical passages in order to look for hermeneutical keys to interpret these age-old texts within current times, averse from any dogmatic preconceptions. ${ }^{1}$ As Spangenberg rightly understood, Biblical texts cannot simply be used in order to justify or explain today's practices. ${ }^{2}$ Indeed, numerous OT passages present today's readers with a real problem and challenge. On the one hand, they appear to be beautifully composed literary creations in which the author used his creativity to the best

* Article submitted: 10/01/2017; peer-reviewed: 13/02/2017; accepted: 3/05/2017. To cite: Hans Ausloos, "The Story of Ehud and Eglon in Judges 3:12-30: A Literary Pearl as a Theological Stumbling Block," Old Testament Essays 30/2 (2017): 225239, doi: http://dx.doi.org/10.17159/2312-3621/2017/v30n2a3

1 Izak J. J. Spangenberg, Perspektiewe op die Bybel: God se woord in mensetaal (Kaapstad: Van Schaik, 1998), 134: "Wie verouderde sienings en uitlegmetodes verabsoluteer en dit as die enigste korrektes klassifiseer, mag wel meen dat hulle besig is om God se eer te verdedig, maar sal later vind dat hulle self hout aangedra het na die brandstapel."

2 See the cover page of Spangenberg's most recent book, illustrating how the Bible is interwoven with the antique worldview. Izak J. J. Spangenberg, Teologie op die markplein (Centurion: Biblaridion, 2016). 
of his abilities in order to form a text of high literary quality. This is certainly the case when one goes beyond a superficial reading of the text. On the other hand, these passages often show themselves to be highly problematic from a modern theological point of view. In strong contrast to their high literary character, the contents of these texts are often gruesome, bringing great difficulties to efforts to proclaim the Bible and undoubtedly underlying negative views of the OT. One of these difficult texts can be found in the story of the Israelite judge Ehud and his clever yet brutal murder of the Moabite King Eglon, as transmitted in Judg 3:12-30.

The first part of this contribution - which I dedicate to Sakkie - will demonstrate how the author of this text has fully succeeded in writing a work of "literature." In particular, the way he plays with words and the way in which he challenges the reader to interpret the text is remarkable. In the second part, I will depart from a rather theological angle and ask the question of how one specific and often-overlooked aspect of the violent nature of the text holds the key to unlocking the theological meaning of the text.

\section{B JUDGES 3:12-20 AS PART OF THE BOOK OF JUDGES}

The Book of Judges is counted among the so-called "historical books" of the OT that recount the "history" of ancient Israel. The books of Joshua, Samuel and Kings, among others, are also included in this genre. Following the Book of Joshua's account of how the Israelites succeeded in taking possession of and settling the promised land, the Book of Judges continues the story of Israel's fate, describing the period before the people were led by a king.

As long as there remained some Israelites still alive who could testify as to how Yahweh had freed them from slavery in Egypt and given them possession of the Promised Land, Israel remained true to its God, though not without stumbling. But once this generation died out, the people began systematically following other gods. With clockwork regularity - Wellhausen correctly spoke about "eine Art Leitartikel" 3 - Israel swapped YHWH for the Canaanite god Baal, and as punishment for their disloyalty, YWHW delivered Israel over to enemies and plunderers. Nevertheless, at the moment of greatest need, and once the Israelites had repented, YHWH, mindful his mercy, repeatedly brought forth people who would liberate Israel and restore peace in the land. These saviours are called "judges," and the eponymous Book of Judges tells the stories of these saviour figures. The concept of judging, however, does not do full justice to the Hebrew term שפט, of which it is the translation. This Hebrew verb means "to lead," and these "judges" thus set Israel back on the right track. Ehud, whose picaresque story is told in Judg 3,12-30, plays the role of one such

3 Julius Wellhausen, Die Composition des Hexateuchs und der historischen Bücher des Alten Testaments (Berlin: Georg Reimer, 1899), 213. 
"judge," even though the Hebrew term שפט does not appear anywhere in the story of which he is the protagonist.

\section{THE STORY OF EHUD AND EGLON}

The main outline of the story of the "judge" Ehud follows the stereotypical pattern of the judge stories. They always begin with the rebelliousness of the people against YHWH. As punishment, YHWH sends hostile people who dominate the Israelites. Israel then repents, and God sends a "judge" to defeat the enemies and restore peace in the land. The specific contribution of each "judge" is mostly situated in the manner in which he or she overthrows the enemy. In Judg 3:12-30, it is primarily the cunningness of Ehud - and the storyteller that steers the story. ${ }^{4}$

\section{$1 \quad$ A Judge with Two Right Hands (Judg 3:12-15)}

Once again the Israelites are doing something displeasing to YHWH. As punishment for their misconduct, YHWH delivers them into the hands of the king of the Moabites, ${ }^{5}$ a people presented as Israel's archenemy in almost the entire biblical tradition. Eglon, the king of Moab, concludes an alliance with the Ammonites and Amalekites - nations equally hostile to Israel - and together they successfully wage war against Israel and occupy the "city of palms." Based on Deut 33:3 and 2 Chr 28:15, the "city of palms" has most often been identified with Jericho. ${ }^{6}$ The fact that Gilgal, a city close to Jericho, also plays a role in the text situates the scene in the area around the Dead Sea. For eighteen years, the Israelites remain under Eglon's rule.

Fully conforming to the aforementioned fixed pattern in the Book of Judges, at a given moment the Israelites repent and call upon YHWH. Likewise following this pattern, YHWH hears their call and raises up a saviour for them. In this case, it is the yet-unmentioned Ehud. He is the son of a certain Gera and

4 For the change in perspective, see above all André Wénin, "Le 'point de vue raconté,' une catégorie utile pour étudier les récits bibliques? L'exemple du meurtre d'Églon par Éhud (Jdc 3,15-26a)," ZAW 120 (2008): 14-27.

5 On the anachronistic nature of the story, see Marc Zvi Brettler, The Creation of History in Ancient Israel (London: Routledge, 1995), 83.

6 J. Alberto Soggin "Ehud und Eglon: Bemerkungen zu Richter iii 11b-31," VT 39 (1989): 96. On the origin of the concept of a Moabite king residing at Jericho, see Ernst Axel Knauf, "Eglon and Ophrah: Two Toponymic Notes on the Book of Judges," JSOT 51 (1991): 25-44. A rather historising view is given by Andreas Scherer, Überlieferungen von Religion und Krieg: Exegetische und religionsgeschichtliche Untersuchungen zu Richter 3-8 und verwandten Texten, WMANT 105 (Neukirchen: Neukirchener Verlag, 2005), 40. 
a "son of Jemini" (בן הימיני). As such, the text seems to suggest that he belongs to the tribe of Benjamin. ${ }^{7}$

Ehud's right hand is said to be אטר (v. 15). The meaning of this circuitous formulation is unclear. Moreover, the term only occurs twice in the HB (Judg 3:15 and 20:16). From the point of view of content, the term seems nevertheless to be crucial to the further development of the story. According to some, the author means to say that Ehud has a handicapped right hand, implying that he is left-handed. ${ }^{8}$ That could explain why Ehud is forced to fasten his dagger to his right thigh (v. 16). Against this interpretation, however, one could point to Judg 20:16, which uses the same terminology to describe seven hundred soldiers from the tribe of Benjamin as "slingers who could hurl their stones at a hair and never miss." It is quite implausible that all seven hundred fighters would be left-handed due to a handicap to the right hand. ${ }^{9}$ It is far more likely that the Benjaminites, according to the biblical tradition, were specially trained to fight with the left hand. ${ }^{10}$ The adjective אטר could therefore have some connection to a practice whereby the right hand would be bound in order to train left-handedness. ${ }^{11}$ In combat, where attack and defence tactics as well as weapons and equipment were mostly based on right-handedness, lefthandedness could offer an advantage. It would have caught opponents by surprise, as they would mostly have faced right-handed fighters. The oldest translation of the Bible, the Greek translation known as the Septuagint from the 2nd

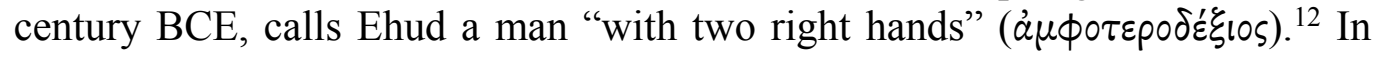
other words, someone who was both left-handed and right-handed.

Whatever the case, this physical description of Ehud brings us in contact with a brilliant example of old-Israelite storytelling that assigns great importance to word- and number-play. ${ }^{13}$ The tribe of Benjamin is usually referred

7 The Benjaminite Gera is mentioned in Gen 46,21.

8 Baruch Halpern "The Assassination of Eglon: The First Locked-Room Murder Mystery," BRev 4/6 (1988): 34

9 Erwin Jugel and Heinz-Dieter Neef, "Ehud als Linkshänder: Exegetische und medizinische Anmerkungen zu Ri 3,15," BN 97 (1999): 46.

10 Ferdinand Dexinger, "Ein Plädoyer für die Linkshänder im Richterbuch," $Z A W 89$ (1977): 209.

11 On the left-hand as a literary motif, see Cristiano Grottanelli, Kings and Prophets: Monarchic Power, Inspired Leadership \& Sacred Text in Biblical Narrative (New York: Oxford University Press, 1999), 52-53.

12 Philip E. Satterthwaite, "Judges," in A New English Translation of the Septuagint and the Other Greek Translations Traditionally Included under That Title, ed. Albert Pietersma and Benjamin G. Wright (New York: Oxford University Press, 2007), 204 translates the Greek word as "ambidextrous."

13 Valérie Kabergs and Hans Ausloos, "Paronomasia or Wordplay? A Babylonian Confusion: Towards A Definition of Hebrew Wordplay,” Bib 93 (2012): 1-20. 
to with the proper name בנימין, but Judg 3 avoids using it. ${ }^{14}$ Instead, it calls Ehud a "son of the right hand" (בן הימיני). This cannot be a coincidence. Furthermore, the author does not write that Ehud is "left-handed" - a term that he did use in Judg 3:21 (יד שמאלו) - but that he's אטר on the right hand, whatever this may actually mean. Although Ehud's "left-handedness" appears at first glance to be nothing more than a banality, its significance to Ehud's mission will become clear later in the story (vv. 16 and 21).

\section{$2 \quad$ Ehud's Mission (Judg 3:16-18)}

Judges 3:15 ends by reporting that the Israelites at a given moment sent Ehud on a mission to pay tribute to Eglon, the king of Moab. Ehud makes preparations that seemingly have nothing to do with this mission, but have everything to do with his task to liberate Israel. He has a double-edged sword made with a length of one גמד ${ }^{15}$ Once again, the Hebrew text presents us with various problems of interpretation.

Translated literally, v. 16 reads: "Ehud made a sword for him." The Hebrew here is ambiguous. The part "for him" (לו) could be used reflexively. ${ }^{16}$ In that case, the text would say that Ehud made a sword for himself. However, this "for him" could also refer to Eglon. Interpreted in this way, the purpose for which Ehud had the sword made would immediately be clear to the reader. It would namely be a weapon with which he would kill the Moabite king, thereby liberating Israel. The words therefore have a different meaning for the reader than they do for Eglon. ${ }^{17}$

Ehud hides the sword under his clothes, affixing it to his right thigh. This is unusual, as a sword is usually worn on the left side to make it easier to draw out with the right hand. The text does not give any explicit indication of why Ehud wears his sword on the right side. Presumably it has something to do with Ehud's right hand that is אטר. One thing is certain. Ehud gives the impression of being harmless, as he carries no weapon on the customary left thigh. The thematic right-left therefore appears once again in the story. Ehud thus goes to Eglon to pay the tribute of the Israelites, armed in an invisible way.

14 Yairah Amit, The Book of Judges: The Art of Editing, trans. Jonathan Chipman, BibInt 38 (Leiden: Brill, 1999), 179-180; Ulrich Hübner "Mord auf dem Abort? Überlegungen zu Humor, Gewaltdarstellung und Realienkunde in Ri 3:12-30," BN 40 (1987): 133. See, for example, Judg $5: 14 ; 10: 9 ; 19: 14$. We find a typical feature of old-Hebrew literature in the description of Ehud, namely the so-called "step parallelism" in which the last word of one verse is taken up in the next verse: Ehud, the son of Gera - son of Ben-Jamin - his right hand (jamin) is "itter."

15 Joshua Berman, “The 'Sword of Mouths' (Jud. iii 16; Ps. cxlix 6; Prov. v 4): A Metaphor and Its Ancient Near Eastern Context," VT 52 (2002): 291-303.

16 Paul Joüon and Takamitsu Muraoka, A Grammar of Biblical Hebrew, SubBi 14 (Rome: Pontificio Istituto Biblico), 545

17 Wénin 'Le 'point de vue raconté,' 17. 
There are two more elements in the description of Ehud's preparation for his mission that a superficial reading can overlook. Important things are communicated with respect to both Ehud's sword and King Eglon.

The length of the sword is mentioned. It is one גמד long. This term is problematic, as it is a hapax legomenon within the old-Hebrew literature. It goes without saying that to recover the meaning of a term used only once in the entire body of literature of a dead language is no cakewalk. ${ }^{18}$ The interpretations of the term גמד that have been given through the ages - the length of the sword varies in the literature from roughly 20 to 45 centimetres - have been inferred primarily from the context of the story. ${ }^{19}$ People mostly let themselves be led by two historicising elements. On the one hand, the sword must be short enough to make it possible for Ehud to smuggle it into the palace, hidden under his clothes on the unlikely right thigh. On the other hand, one supposes that the sword must have been long enough to kill the king. ${ }^{20}$ This brings us to the characterisation of Eglon, with v. 17 stating that the king of Moab was very fat.

In his description of Eglon, the author makes wonderfully creative use of the Hebrew language. The Hebrew term used to describe Eglon as "meaty" (איש בריא מאד) is rarely used in OT literature to refer to humans. ${ }^{21}$ It mostly refers to animals. One finds this term, for example, in the description of Joseph's dream, where he sees seven fat cows being devoured by seven thin cows (Gen 41:1-4). The fact that the author chooses precisely this term to describe Eglon undoubtedly betrays his intention: he sees the king of Moab as a fat beast ready to be slaughtered. ${ }^{22}$ It appears to be no coincidence that the name Eglon

18 On the use of hapax legomena in Judg 3:12-20 and their rendering by the Septuagint translator, see Hans Ausloos and Bénédicte Lemmelijn, "Characterizing the LXX Translation of Judges on the Basis of Content-Related Criteria: The Greek Rendering of Hebrew Absolute Hapax Legomena in Judg 3,12-30," in After Qumran: Old and Modern Editions of the Biblical Texts: The Historical Books, ed. Hans Ausloos, Bénédicte Lemmelijn and Julio Trebolle Barrera (Leuven: Peeters, 2012), 171-192.

19 T. A. G. Hartmann, "גמדin Richter 3:16 oder die Pygmäen im Dschungel der Längenmaße.” ZAH 13 (2000): 188-193.

20 See in particular Lawson G. Stone, "Eglon's Belly and Ehud's Blade: A Reconsideration," JBL 128 (2009): 649-663, and James K. Aitken, "Fat Eglon," in Studies on the Text and Versions of the Hebrew Bible in Honour of Robert Gordon, ed. Geoffrey Khan and Diana Lipton (Leiden: Brill, 2012), 141-154.

21 Compare with Judg 3,29, in which human corpulence is indicated with the term שמן.

22 Gregory Mobley, The Empty Men: The Heroic Tradition of Ancient Israel, ABRL (New York: Doubleday, 2005), 77-78. On the totemic rendering of the king's name as "calf," see Heinz-Dieter Neef, "Eglon als 'Kälbermann'? Exegetische Beobachtungen zu Jdc 3:12-30," VT 59 (2009): 288-289. 
is related to the Hebrew word עגל which means "bull."23 For the attentive reader it is consequently obvious that, from the very beginning, Ehud's mission is to kill Eglon the slaughter-ready bull. ${ }^{24}$ Or rather, to sacrifice him. In addition to the notion of the "fat bull," there are, indeed, other terms in this pericope with the connotation of a ritual offering. I mention here only the term מנחה ("sacrifice"), which is used in Judg 12:15, 17, 18. This term appears primarily in the context of ritual sacrifice in the OT. ${ }^{25}$

It may be clear by now that the story has a double bottom. Eglon perceives the events in a different way than the reader. From Eglon's perspective, Ehud brings a public "sacrifice" on behalf of Israel - he is a messenger of Israel. But at the same time, the attentive reader has an eye for Ehud's underlying, secret mission - he must sacrifice Eglon the "fat bull." Through this liberating act, Ehud is also a messenger of God who wants to free his people. Precisely this mission stands central in the unfolding of the story.

\section{$3 \quad$ Ehud as Secret Agent (Judg 3:19-26)}

Once the tribute has been delivered to Eglon, Ehud heads home together with the Israelite bearers who carried the tribute. For Eglon, it looks like the mission has been completed. He has received what he believes he is entitled to. Ehud, however, turns around at the "sculptured stones" (הפסילים) and heads back to Eglon (v. 19).

The mention of the "sculptured stones" obviously has a structuring function in the pericope of Judg 3:12-30. They do not appear only at the beginning of the pericope. They also appear at its end. Their function in the story is therefore to enclose the episode about Ehud's secret mission. Vv. 19-26 thereby form the core of the story that is framed between vv. 12-25 (Israel's dependence) and vv. 27-30 (Israel's victory). These central verses (19-26) are clearly structured, as shown by the word use:

3:19a: the פסילים ("sculptured stones")

3:19b-20a: Eglon's servants leave (יצא) and Ehud approaches (בוא)

3:20b-23: in Eglon's private royal chamber

3:24: Ehud leaves (יצא) and the servants approach (בוא) 3:26: the פסילים ("sculptured stones")

23 Contra Jack M. Sasson, "Ethically Cultured Interpretations: The Case of Eglon's Murder (Judges 3)," in Homeland and Exile: Biblical and Ancient Near Eastern Studies in Honour of Bustenay Oded, ed. Gershon Galol, Mark Geller, and Alan Millard, VTSup 130 (Leiden: Brill, 2009), 573.

24 Soggin "Ehud und Eglon," 96.

25 See, for example, Lev 2:1,4, 5, 6, 15; 6:13; Num 15:6. 
Why the author explicitly names precisely these פסילים at Gilgal is unclear. The term appears about 20 times in the OT, mostly with the negative meaning of "idols." This is, however, not an immediate reason to assume that the פסילים in Judg 3:19.26 also have a negative connotation-on the contrary. For the reader, they call to mind the stones that the Israelites had set up at Gilgal after crossing the Jordan (Josh 4:20-24). It therefore cannot be ruled out that the "sculptured stones" in Judg 3:19, 26 have a religious connotation as well. According to Josh 4:24, the stones had a double meaning. Through these stones, all nations would remember how mighty YHWH is, and Israel would continue to fear him. Precisely these two elements are also addressed in Judg 3:12-20. Furthermore, the פסילים in Judg 3:19.26 delineate a border. Between the moment when Ehud makes an about-face at the פסילים and the moment when he walks by again, something crucial happens, namely the death of Eglon.

When Ehud reaches the king again, he knows that he must immediately draw the king's attention. He says, "O King, I have a secret for you." Once again, we are confronted with the ambiguity of the Hebrew language. The text literally says, "I have a secret דבר for you" (v. 19). This Hebrew term has a double meaning. The first is "word," and that is how Eglon also interprets it as the announcement of a secret message. He immediately demands silence, an order interpreted by the others present as a command to leave and let Eglon and Ehud talk to each other in private. The fact that Ehud is no longer accompanied by the Israelite bearers makes it even more exciting for the king, but it also sets him at ease. Little threat can be expected of a solitary, seemingly unarmed man. However, in addition to "word," דבר also means "thing" or "object." For the reader, it is immediately clear what the author is referring to, namely the dagger that Ehud is carrying.

According to the text, Ehud takes one more step closer to the king. He goes into the upper chamber - a place usually reserved for the king alone. Having entered, Ehud says, "I have a דבר for you from God." This feeds Eglon's curiosity even more. Ehud has indeed come because of God. Once again the ambiguous term דבר is used, and interpreted by Eglon in a different way than the reader. For the (Israelite) reader, it's clear. He's thinking of the weapon (דבר as "thing") that will, thanks to the divinely sent Ehud, herald the end of the Moabite oppression. For Eglon, the message becomes even more mysterious (דבר as "word"). It appears not only to be secret, the words seem moreover to be a divine oracle. He rises, perhaps out of respect. At that moment, Ehud grabs the sword from his right thigh with his left hand and stabs the king in the belly.

In contrast to other biblical passages that describe murder - the story of Cain's murder of his brother Abel comes to mind (Gen 4:1-17) - the murder of Ehud is described with much attention paid to the gruesome details. The text 
continues with the first part of v. 22: "After the blade, the hilt of the sword also pushed in (to Eglon's belly). And the fat closed over the blade. He (Ehud) did not pull the sword out." Besides the dead body of Eglon, no traces are left from this "clean murder." 26

The last part of v. 22 is once again problematic. ${ }^{27}$ In the Hebrew text, there are only two words (ויצא הפרשדנה), each of which presents us with many difficulties in interpretation. The verb is a third person masculine singular form

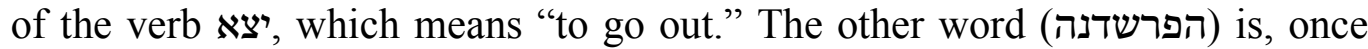
again, a hapax legomenon - in other words, a term about which we are in the dark concerning both its meaning and its origin. One could see the notexplicitly-named Ehud as the subject of the verb, and interpret the term as an opening through which Ehud can escape after the murder. This interpretation is, however, problematic. Indeed the following verse says again that Ehud - and here he is called by name - goes away. Others therefore consider the unknown term הפרשדנה, and not Ehud, to be the subject of the verb. This noun is then seen as being related to the noun פרש, which is most often interpreted as the content of Eglon's belly or intestines. ${ }^{28}$ Based on this etymological interpretation, the majority of English translations of the Bible come to the following view: "and the dirt/dung [of Eglon] came out." This interpretation would fit the comments given by Eglon's servants when Eglon has them wait on him: "He is only relieving himself in the cool room" (v. 24). ${ }^{29}$

The following verse (v. 23), which describes Ehud's escape, also presents us with difficulties. To begin with, the interpretation of this verse is also made difficult by the presence of a hapax legomenon, namely the term המסדרונה. If one interprets the prefix ה- as an article and the last consonant (ה-) as a suffix indicating direction, one is left with the base מסדרון. From an etymological perspective, this word may be related to the verb סדר which means "to order." The noun מסדרון could then mean something like "corridor," which could possibly refer to the front hall of the palace. Verse 23 then says that Ehud closes the doors. The question that presents itself here is, does Ehud pull the upper chamber's doors shut when he leaves? And does he close them from the the outside or from the inside?

26 Hartmut N. Rösel, “Zur Ehud-Erzählung," ZAW 89 (1977): 271; Amit, Book of Judges, 187.

27 Michael L. Barré, “The Meaning of pršdn in Judges 3:22.” VT 41 (1991): 2-6.

28 See the usage of the term in Exod 29:14; Lev 4:11; 8:17; 16:27; Num 19:5; Mal $2: 3$.

29 Grammatically speaking, the blade (נצב) can also be taken as the subject. Deist, for example, translates the term הפרדסנה as "anus": "The blade went into the direction of his anus." As such, the exit ה- is understood as an indicator of direction. See Ferdinand Deist, "'Murder in the Toilet' (Judges 3:12-30): Translation and Transformation," Scriptura 58 (1996): 265. 
One often chooses the latter interpretation. In this case, Ehud would have to make use of a secret exit in order to be able to leave the upper chamber. In this case, the secret exit was: the opening (or a window) of the toilet. ${ }^{30}$ In the subsequent text, one reads how, after Ehud has left, the servants notice that the doors of the upper chamber are locked. ${ }^{31}$ This makes them assume that the king is "covering his feet" - a euphemism mostly interpreted to mean "doing his business" 32 - "in the cool chamber." 33 In other words, there must have been a toilet somewhere in the king's throne room, and Ehud would then have escaped through the opening in the toilet. This hypothesis has led to all sorts of guesswork concerning the architecture of Eglon's palace. Baruch Halpern, for example, supposes that Eglon's throne room was above a space called the After locking the doors from the inside, Ehud would then have gone through the toilet and descended into the המסדרון room, which was under the throne room. From there, he would have walked through the reception hall and front hall to the outside without arousing any suspicion. After seeing Ehud leave, the servants would have returned to the reception hall, and upon noticing the locked doors, they would have remembered that the king was taking care of his bodily needs.

Whatever the case, with the passage of time, the servants obviously get worried as Eglon doesn't open the door. They retrieve a key and open the door themselves to find their king dead on the floor. ${ }^{35}$ Needless to say, Ehud has by

30 This interpretation of the term has been given an impetus by Marie-Joseph Lagrange, Le livre des Juges, EBib (Paris: Victor Lecoffre, 1903), 55-56, and has been followed partly by Charles F. Burney, The Book of Judges: With Introduction and Notes (London: Rivingtons, 1918), 72-73.

31 On the role of the servants, see in particular Amit, Book of Judges, 191-194.

32 Soggin, "Ehud und Eglon," 97.

33 Halpern, "Assassination," 32-41, disputes this translation. To begin with, he states that 'coolness' - a rendering of the Hebrew term מקרה - is not an architectural notion, as one would expect in this context. He therefore considers it a contradiction in terms to relate precisely the 'upper chamber' (עליה) to 'coolness.' In the area around the Dead Sea, where the story is situated, coolness would not be found on the upper floors. On the contrary, the ground floor would be where it feels cool. Halpern therefore presents an alternative interpretation, basing himself on Ps 104:2-3, which reads, God "has stretched out the heavens like a tent and laid the beams (מקרה) of his chambers (עליו) over the waters." On the basis of these verses, Halpern interprets the term מקרה in Judg 3:24 as "beams." The "cool upper chamber" would then rather be "the upper chamber on the beams" (Halpern, "Assassination," 38). According to Neef, "Eglon," 291, the verb would have to be translated as "to rub with oint." Eglon would therefore have retreated into his chamber for reasons of (intimate?) hygiene.

34 Halpern, "Assassination," 33-44.

35 According to Zvi Brettler, Creation of History, 82, 192 the terminology of the opening and closing of the doors, which has garnered much attention in this pericope, carries sexual connotations. To demonstrate his point, he refers to the way in which 
that time disappeared far out of sight. Just like in v. 19, the "sculptured stones" once again form a turning point. As the text in v. 19 had stated how Ehud had turned back for Eglon from this point, it is no coincidence that these "sculptured stones" would be mentioned once again after the conclusion of the mission. They are the "border stones" demarcating the passageway between life and death - both for Eglon and the Israelites.

\section{Eglon's Death and Israel's Survival (Judg 3:27-30)}

As soon as he reaches Israelite territory in Ephraim (v. 27), Ehud sounds the trumpet and establishes himself as Israel's leader. At this point, YHWH once again makes his entry upon the story explicit. It is YHWH who will deliver the Moabites into the Israelites' hands (v. 28). An inclusio is thus formed with v. 12, in which YHWH delivered Israel over to Moab. Under Ehud's leadership, the Israelites occupy all the wadable spots of the Jordan so that the Moabites cannot cross. The Israelites then kill "ten thousand Moabites, all strong, ablebodied men." And in order to put even more force into the deed of the Israelites, the author concludes, "Nobody escaped" (v. 29). The goal has been achieved, as thanks to Ehud, "the land had eighty years of rest" (v. 30). Also in terms of form, the story comes to a conclusion. As the author had said in v. 13 that Eglon "defeated" Israel, in v. 29 it is the Israelites who "defeat" Moab. In either case, the Hebrew verb נכה is used.

Moab's downfall, however, by no means signifies the end of the story of Israel's rebelliousness against YHWH, for "after the death of Ehud, the Israelites once again displeased YHWH" (Judg 4:1). This disobedience would be the occasion for the emergence of Deborah as "judge" in Israel.

\section{EHUD, EGLON AND DIVINE VIOLENCE}

For a biblical scholar, Judg 3:12-30 is a precious text. It enables the exegete to demonstrate that the biblical authors were extremely proficient storytellers, as well as to show how they were such good storytellers. Not only is the story of Ehud and Eglon thoughtfully composed, it also has numerous keywords that lend cohesion to the story. Like no other, Judg 3:12-30 bulges with numerous forms and wordplays, which unfortunately mostly get lost in translation. Less brilliant, however, is the brutal violence with which the text confronts today's reader. And it is precisely this that strikes, or rather shocks, today's reader who for the most part reads the text in translation. ${ }^{36}$ Not only is there the brutal murder of Eglon and the fact that YHWH ruthlessly delivers the Moabite king into Israel's hands, YHWH also hands the Israelites over to the Moabites in the

these terms are used in Song 5:2 and 4:12. The "sword" and the fact that the term "hand" also appears frequently in this pericope could also point in this direction, as the term "hand" is often used in OT literature as a euphemism for the phallus.

36 Deist, "“Murder in the Toilet,"” 266-271. 
beginning of the story. And it is precisely this aspect, which at first glance complicates things even more, that holds the key to the understanding of this text.

God and violence are inseparable in the OT, regardless of how many texts also bring a peaceful and loving God to the fore. This is not the place to comprehensively address this general issue. I only want to make some simple remarks in connection to the pericope of Ehud and Eglon without lapsing into general statements. ${ }^{37}$ The violence in Judges 3,12-30 must always be seen against the background of the tenor of the entire Book of Judges, even if it is quite possible that the Ehud story originated as a profane story of a hero, completely lacking in any religious connotations, only to be reworked later by a (deuteronomistic?) redactor into a theological story, and therefore came to be included as a part of the Book of Judges.

To begin with, it is striking that God's violence in this pericope initially falls not upon Israel's enemies, but upon Israel itself. It is, in other words, not about divine violence against Israel's oppressors with the goal of liberating the Israelites from a humiliating situation, as it was in the story of the exodus from Egypt. On the contrary. The beginning of the pericope clearly stresses, "YHWH gave Eglon, the king of Moab, power over Israel" (Judg 3:12). By handing Israel over to the Moabites, God turns against Israel and makes use of a hostile nation. The divine violence is here part of a divine pedagogy - a theology that has become very problematic. God punishes the Israelites because they have turned away from him and followed other gods. However, at the same time, it doesn't remain at the level of punishment. Each time that Israel repents and returns to YHWH, God shows himself to be merciful: "YHWH is a merciful and gracious God, patient, great in love and faithfulness, who shows goodness into the thousandth generation, who forgives misdeeds, transgressions and sins, but does not let the guilty remain unpunished" (Exod 34:6-7).

The author has no problems with the divine pedagogy making use of others. His aim is to show his readers how Israel continuously falls on the wrong side, is punished by God, and is ultimately set back on the right path. This is the message the author has for his readers. First, the author explains to his readers how the Israelites become victims of their own sinfulness, over and over again, and how this misery is of their own doing. Next, the author seeks to encourage Israel to draw lessons out of its past and avoid falling back into idolatry again. The fact that the author uses precisely the Moabites for this reeducation process of the Israelites testifies all the more to his talent as an au-

37 An excellent and nuanced presentation of divine violence in the OT can be found in André Wénin, “Adonaï est un guerrier' (Ex 15,2): La violance divine dans le premier Testament," in Divine Violence: Approche exégétique et anthropologique, ed. Jean-Daniel Causse, Élian Cuvillier and André Wénin, LlB 168 (Paris: Cerf, 2011), $15-66$. 
thor. Time and again the OT recounts how Israel and Moab lived constantly at war with each other. When the author pokes fun at the fat king of Moab in the most gruesome way, showing how the king was sacrificed like a bull for a good cause - as such, the story has been characterised as "ethnic humor" 38 or "verbal feud" 39 - the Israelites must undoubtedly have grinned with malicious pleasure. As narrative theologian par excellence the author of Judg 3:12-30 succeeds like no other in communicating his "deuteronomistic" message through a wonderfully composed story: things will go poorly for the one who turns away from God. But at the same time, he also attests to the certainty that God does not shun those who return to him. Despite all the unbelief and unfaithfulness, he always takes the Israelites back, and he is - at least for those who align themselves with him - a God of life.

\section{BIBLIOGRAPHY}

Aitken, James K. "Fat Eglon." Pages 141-154 in Studies on the Text and Versions of the Hebrew Bible in Honour of Robert Gordon. Edited by Geoffrey Khan and Diana Lipton. Leiden: Brill, 2012.

Amit, Yairah. The Book of Judges: The Art of Editing. Translated from the Hebrew by Jonathan Chipman. Biblical Interpretation Series 38. Leiden: Brill, 1999.

Ausloos, Hans and Bénédicte Lemmelijn. "Characterizing the LXX Translation of Judges on the Basis of Content-Related Criteria: The Greek Rendering of Hebrew Absolute Hapax Legomena in Judg 3,12-30." Pages 171-192 in After Qumran: Old and Modern Editions of the Biblical Texts: The Historical Books. Edited by Hans Ausloos, Bénédicte Lemmelijn and Jiulio Trebolle Barrera. BETL 246. Leuven: Peeters, 2011.

Barré, Michael L. "The Meaning of pršdn in Judges 3:22." VT 41 (1991): 1-11.

Berman, Joshua. "The 'Sword of Mouths' (Jud. iii 16; Ps. cxlix 6; Prov. v 4): A Metaphor and Its Ancient Near Eastern Context." VT 52 (2002): 291-303.

Burney, Charles F. The Book of Judges: With Introduction and Notes. London: Rivingtons, 1918.

Deist, Ferdinand. "'Murder in the Toilet' (Judges 3:12-30): Translation and Transformation.” Scriptura 58 (1996): 263-272.

Dexinger, Ferdinand. "Ein Plädoyer für die Linkshänder im Richterbuch." $Z A W 89$ (1977): 268-269.

Grottanelli, Cristiano. Kings and Prophets: Monarchic Power, Inspired Leadership \& Sacred Text in Biblical Narrative. New York: Oxford University Press, 1999.

Halpern, Baruch. "The Assassination of Eglon: The First Locked-Room Murder Mystery." Bible Review 4/6 (1988): 32-41.

Handy, Lowell K. "Uneasy Laughter: Ehud and Eglon as Ethnic Humor." SJOT 6 (1992): 233-246.

38 Lowell K. Handy, "Uneasy Laughter: Ehud and Eglon as Ethnic Humor," SJOT 6 (1992): 223.

39 Geoffrey P. Miller, "Verbal Feud in the Hebrew Bible: Judges 3:12-30 and 1921.” JNES 55 (1996): 105. 
Hartmann, T. A. G. "גמדin Richter 3:16 oder die Pygmäen im Dschungel der Längenmaße." ZAH 13 (2000): 188-193.

Hübner, Ulrich. "Mord auf dem Abort? Überlegungen zu Humor, Gewaltdarstellung und Realienkunde in Ri 3:12-30." BN 40 (1987): 130-140.

Joüon, Paul and Takamitsu Muraoka. A Grammar of Biblical Hebrew. Subsidia Biblica 14. Rome: Pontificio Istituto Biblico, 1993.

Jugel, Erwin and Heinz-Dieter Neef. "Ehud als Linkshänder: Exegetische und medizinische Anmerkungen zu Ri 3,15.” BN 97 (1999): 45-54.

Kabergs, Valérie and Hans Ausloos. "Paronomasia or Wordplay? A Babylonian Confusion: Towards A Definition of Hebrew Wordplay." Bib 93 (2012): 1-20.

Knauf, Ernst Axel. "Eglon and Ophrah: Two Toponymic Notes on the Book of Judges." JSOT 51 (1991): 25-44.

Lagrange, Marie-Joseph. Le livre des Juges. EBib. Paris: Victor Lecoffre, 1903.

Miller, Geoffrey P. "Verbal Feud in the Hebrew Bible: Judges 3:12-30 and 19-21." JNES 55 (1996): 105-117.

Mobley, Gregory. The Empty Men: The Heroic Tradition of Ancient Israel. ABRL. New York: Doubleday, 2005.

Neef, Heinz-Dieter. “Eglon als 'Kälbermann'? Exegetische Beobachtungen zu Jdc 3:12-30." VT 59 (2009): 284-294.

Rösel, Hartmut N. “Zur Ehud-Erzählung.” ZAW 89 (1977): 270-272.

Satterthwaite, Philip E. "Judges." Pages 195-238 in A New English Translation of the Septuagint and the Other Greek Translations Traditionally Included under That Title. Edited by Albert Pietersma and Benjamin G. Wright. New York: Oxford University Press, 2007.

Sasson, Jack M. "Ethically Cultured Interpretations: The Case of Eglon's Murder (Judges 3)." Pages 571-595 in Homeland and Exile: Biblical and Ancient Near Eastern Studies in Honour of Bustenay Oded. Edited by Gershon Galil, Mark Geller and Alan Millard. VTSup 130. Leiden: Brill, 2009.

Scherer, Andreas. Überlieferungen von Religion und Krieg: Exegetische und religionsgeschichtliche Untersuchungen zu Richter 3-8 und verwandten Texten. WMANT 105. Neukirchen: Neukirchener Verlag, 2005.

Soggin, J. Alberto. "Ehud und Eglon: Bemerkungen zu Richter iii 11b-31.” VT 39 (1989): 95-100.

Spangenberg, Izak J. J. Perspektiewe op die Bybel: God se woord in mensetaal. Kaapstad: Van Schaik, 1998. . Teologie op die markplein. Centurion: Biblaridion, 2016.

Stone, Lawson G. "Eglon's Belly and Ehud's Blade: A Reconsideration." JBL 128 (2009): 649-663.

Wénin, André. ““Adonaï est un guerrier' (Ex 15,2): La violance divine dans le premier Testament." Pages 15-66 in Divine Violence: Approche exégétique et anthropologique. Edited by Jean-Daniel Causse, Élian Cuvillier and André Wénin. LIB 168. Paris: Cerf, 2011.

. 'Le 'point de vue raconté,' une catégorie utile pour étudier les récits bibliques? L'exemple du meurtre d'Églon par Éhud (Jdc 3,15-26a)." ZAW 120/1 (2008): 14-27.

Wellhausen, Julius. Die Composition des Hexateuchs und der historischen Bücher des Alten Testaments. Berlin: Georg Reimer, 1899. 
Ausloos, "The Story of Ehud and Eglon," OTE 30/2 (2017): 225-239

Zvi Brettler, Marc. The Creation of History in Ancient Israel. London: Routledge, 1995.

Prof Hans Ausloos, Université catholique de Louvain, Faculté de Théologie, Grand-Place 45 - bte L3.01.01. BE-1348, Louvain-la-Neuve. Email: hans.ausloos@uclouvain.be. 